\title{
Study of Chlorophyll-a Enhancement Over the Northern Arabian Sea
}

\author{
K. Muni Krishna* \\ Department of Meteorology \& Oceanography, Andhra University, Visakhapatnam-530003, India
}

\begin{abstract}
Northern Arabian Sea is one of the most biologically rich region in the North Indian ocean during winter season. In the present study I wish to investigate the the dynamics behind the enrichment of Chlorophyll-a at the above region using multi satellite observations. Ocean Color Monitor (OCM) imageries are used to identify these areas along the west coast of India during February 2000 \& 2001 and the mechanisms that can upwell nutrients to sustain the bloom are investigated using sea surface temperature and winds. The variability of Ekman pumping velocity along the northeast Arabian sea is $0.5-3.0 \times 10^{-6} \mathrm{~m} / \mathrm{s}$ and the Ekman depth is $25-55 \mathrm{~m}$. Sea surface temperature was $1^{0} \mathrm{C}$ cooler in 2001 winter. This increased cooling resulted in more intense convection and vertical mixing.
\end{abstract}

Keywords: Ekman pumping, upwelling, chlorophyll, wind stress curl.

\section{INTRODUCTION}

Coastal Upwelling (CU) is a result of horizontal divergence near the sea surface and manifests itself by the presence at the surface of relatively cold water. When the process occurs over a continental shelf it can have both economic and climatological effects. It takes place most spectacularly off western coast of a continent, along which the eastern boundary currents flow in general.

The ocean colour measurements provide us information on the organic and inorganic suspended materials in the surface layer. Impacts of human activities are transferred from the land to the ocean mainly through the rivers and the coastlines, which changes the ocean colour directly by advection and diffusion or indirectly by the biological and chemical processes. Therefore, to investigate oceanic environment, the ocean colour remote sensing is a key technology. The ocean color sensors have narrow bands of the visible and near infrared and provide a discrete spectrum of target water colour. It is well recognized that the chlorophyll-a concentration can be retrieved well in the clear open oceans from the satellite colour measurements, but there are still some problems for its retrieval in the turbid coastal waters [1].

Monitoring and locating the oceanic features like thermal gradients (fronts), upwelling, eddies and gyres are difficult and expensive by conventional means. The satellite based remote sensing data is unique source for locating and monitoring oceanic features. The satellite borne thermal IR

\footnotetext{
*Address correspondence to this author at the Department of. Meteorology \& Oceanography, Andhra University, Visakhapatnam-530003 India; Tel: +91-891-2844633; Fax: +91-891-2525611;

E-Mail: munikrishnna@yahoo.co.in
}

imagery (Advanced Very High Resolution RadiometerAVHRR) has been used routinely to detect and track the oceanic features. Lauritsen [2] have used AVHRR data to locate temperature fronts and found that fishing efforts \& high catch rates of albacore concentration in the vicinity of these fronts.

Knowledge of spatial variations of vector surface wind stress is critical to understand biological-physical interactions in the north Indian Ocean, where seasonally reversing winds of the monsoon caused by differential heating of ocean and land [3]. The coupled atmosphere-landocean system of the monsoon is one of the Earth's most complex phenomena. In northern hemisphere, winds are northeasterly during the December-March (northeast monsoon). Arabian Sea Currents are highly sensitive to surface wind stress.

The winter cooling phenomena in the northern Arabian Sea occurs due to dry cool continental air brought by northeast monsoon winds [4-7]. Further it enhances evaporation, leading to surface cooling of northern Arabian Sea water [8]. The decrease in incoming solar radiation plays a major role in winter cooling during January and February.

On the basis of the Coastal Zone Colour Scanner data [9], scientists deduced the occurrence of highest chlorophyll concentrations north of $20^{\circ} \mathrm{N}$ during February 1979 - March 1980. The winter convection in the northeastern Arabian Sea leads to elevated pigment values, as does even modest during southwest (summer) monsoon. The northern Arabian Sea is characterized by offshore and onshore chlorophyll blooms during the northeast monsoon period [10]. Yoder [11] has found anomalous pattern of chlorophyll concentration caused by monsoon wind-induced upwelling in the North Indian Ocean compared to the other oceans. 
The primary objective of this study is to identify the variability of coastal upwelling, using OCM Chlorophyll, sea surface temperature (SST) and wind data along the west coast of India $\left(16^{0} \mathrm{~N}-24^{0} \mathrm{~N}\right.$ and $\left.64^{0} \mathrm{E}-74^{0} \mathrm{E}\right)$ during two northeast monsoon seasons.

\section{DATA AND METHODOLOGY}

The data sets used for this study are: 1) Daily OCM Chlorophyll images from IRS-P4, at a spatial resolution of 360m for cloud free conditions, 2) Daily NOAA-18 AVHRR SST and Quickscat Winds from Jet Propulsion Laboratory's web site (http//:podaac.jpl.nasa.gov) for the corresponding days in accordance with the OCM images. The SST and Quick SCAT winds were taken at $1^{0} \times 1^{0}$ and $0.5^{0} \times 0.5^{0}$ latitude and longitude grids respectively.

\section{OCM DATA ANALYSIS}

The launch of the Ocean Colour Monitor (OCM) sensor onboard IRS-P4 satellite has been a boon to the scientific community involved in the analysis and characterization of the chlorophyll concentration in the oceans. The IRS-P4 OCM has eight spectral channels in visible and near-infrared wavelengths $(412-865 \mathrm{~nm})$ with a spatial resolution of $360 \mathrm{~m}$ and revisit cycles of 2 days [12]. OCM have eight bands both in BIL and BSQ mode. Each band is stacked and exported as Generic Binary. These 8 bands Generic Binary data was processed using ERDAS 8.4 (with OCM-DAS module) software. The processed data is then imported in IEEE 32 bit float format depending upon the resultant image quality. For the present study we used path 9 and row 13 OCM data during cloud free days. The study area is shown in Fig. (1).

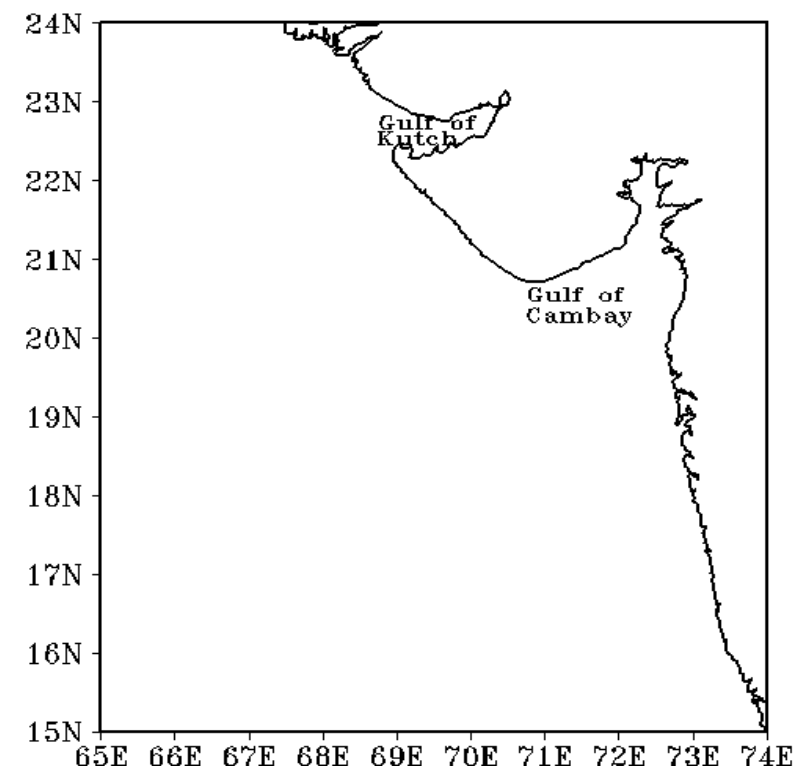

Fig. (1). Study area.

\section{SEA SURFACE TEMPERATURE}

Ever since the launch of AVHRR sensor on NOAA satellite series in 1979, now the present series is NOAA-18, it is providing high resolution sea surface temperature over the global ocean. Latest being NOAA-16, launched in September 2000, the data was downloaded and extracted for the study region to analyse the OCM images and SST data together to find out the upwelling features along the west coast of India. The SST data resolution is $1^{\circ} \times 1^{\circ}$ latitude and longitude bins.

\section{COMPUTATION OF EKMAN PUMPING VELOCI- TIES AND EKMAN DEPTH}

Sea Winds Scatterometer onboard Quickscat satellite measures high resolution sea surface winds of 3 to $20 \mathrm{~m} / \mathrm{s}$ with an accuracy of $\pm 2 \mathrm{~m} / \mathrm{s}$. Using the surface winds, Ekman pumping $(\mathrm{m} / \mathrm{s})$ and Ekman depths $(\mathrm{m})$ were calculated followed by Pond \& Pickard [13] over the study region.

Ekman Pumping $\left(W_{E}\right)$ can be calculated as,

$W_{E}=\frac{\operatorname{Curl}_{z} \tau}{\rho_{w} f}$

Where, $\rho_{w}$ is density of sea water $\left(\mathrm{Kg} \mathrm{m}^{-3}\right)$, $\mathrm{f}$ (Coriolis parameter) is equal to $2 \Omega \sin \phi$, where $\phi$ is the latitude, $\Omega$ is the rotation of Earth $\left(7.29 \times 10^{-5} \mathrm{rad} / \mathrm{sec}\right)$,

$\mathrm{Curl}_{\mathrm{z}} \tau$, the vertical component of wind stress curl $\left(\mathrm{N} \mathrm{m}^{-}\right.$ $\left.{ }^{3}\right)$, is defined by

$$
\operatorname{Curl}_{z} \vec{\tau}=(\nabla x \tau)_{z}=\left(\frac{\partial \tau_{y}}{\partial x}\right)-\left(\frac{\partial \tau_{x}}{\partial y}\right)
$$

Where, $\tau_{\mathrm{x}}$ and $\tau_{\mathrm{y}}$ are zonal and meridional wind stress components respectively.

Ekman Depth ( $D_{E}$ ) can be calculated as,

$$
D_{E}=3091 C_{D}\left(\frac{W}{\sqrt{\sin \phi}}\right)
$$

Where, $\mathrm{W}$ is wind speed $(\mathrm{m} / \mathrm{s}), C_{D}$ is non dimensional drag coefficient $\left(1.3 \times 10^{-3}\right)$.

$\operatorname{Curl}_{z} \tau$ values were computed from daily mean $\tau_{x}$ and $\tau_{y}$ values and the daily mean $\mathrm{W}_{\mathrm{E}}$ and $\mathrm{D}_{\mathrm{E}}$ values were computed for the study region.

\section{RESULTS AND DISCUSSION}

OCM chlorophyll-a images during 9 - 29 February 2000 shows a patch of high chlorophyll-a around $18^{0} \mathrm{~N}, 72^{0} \mathrm{E}$ corresponding to a region of low SST $\left(24^{0} \mathrm{C}\right)$. The chlorophyll concentrations are higher in the northern Arabian Sea, Gulf of Kutch and the Gulf of Cambay ranging between 2-5, 5-8 and $7-10 \mathrm{mg} / \mathrm{m}^{3}$ respectively (Fig. 2). Tang and Kawamura [10] have also found similar chlorophyll concentrations in the northern Arabian Sea using Ocean Color and Temperature Sensor (OCTS) images. The chlorophyll concentrations show scattered distribution with areas of high patches in the Gulf areas and in the Arabian Sea, and these patches are found to be diminishing towards 

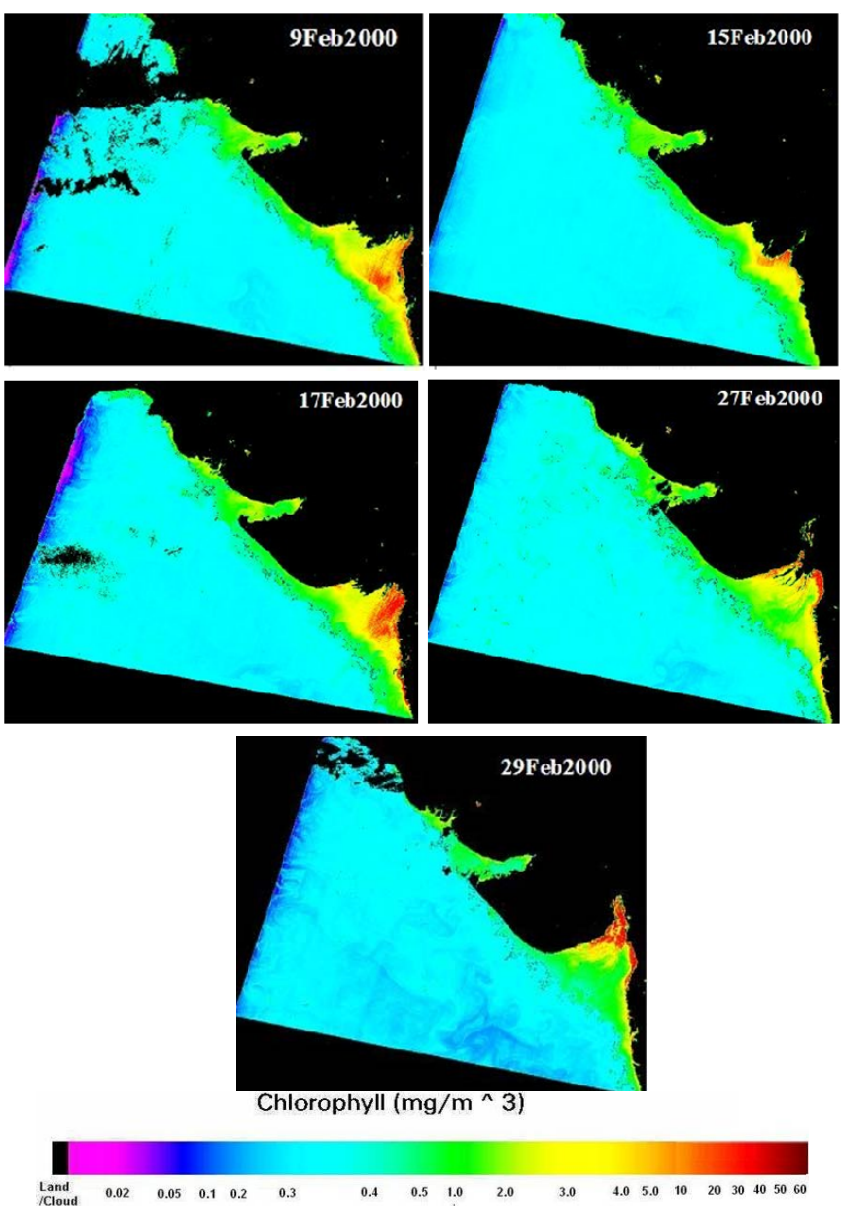

Fig. (2). Spatial distribution of OCM Chlorophyll-a concentration along the west coast of India during 2000.

offshore. In the central part of the Arabian Sea, the chlorophyll concentrations found to be $<0.5 \mathrm{mg} / \mathrm{m}^{3}$.

OCM chlorophyll-a images (Fig. 3.) during $7-23$ February 2001 shows a patch of high chlorophyll-a around $18^{0} \mathrm{~N}, 72^{0} \mathrm{E}$ corresponding to a region of low SST $\left(23^{0} \mathrm{C}\right)$, but the Ekman Pumping (EP) values are almost low and negative. The chlorophyll concentration shows higher values in the northern Arabian Sea $\left(4-9 \mathrm{mg} / \mathrm{m}^{3}\right)$ and in the Gulf of Kutch $\left(4-7 \mathrm{mg} / \mathrm{m}^{3}\right)$ and the Gulf of Cambay $\left(9-15 \mathrm{mg} / \mathrm{m}^{3}\right)$. The chlorophyll concentration in the northeastern coastal regions is found to be higher $\left(>7 \mathrm{mg} / \mathrm{m}^{3}\right)$. Sea surface temperature distribution for the corresponding OCM Chlorophyll images are shown in Fig. (4). The SST values are decreasing with increasing chlorophyll concentrations.

To explore the nature and possible role of Ekman Pumping (EP) in introducing nutrients from sub surface waters, we used daily Quick SCAT winds during Feb 2000 \& 2001 to compute the daily mean wind stress curl, EP and Ekman depth. The February 2000, EP contour distribution (Figs. 5 \& 6) shows the positive Ekman pumping velocity that can give rise to upwelling in the northwest half of the Arabian Sea and the negative distribution (conducive to downwelling) in the Southeast half. The positive distribution
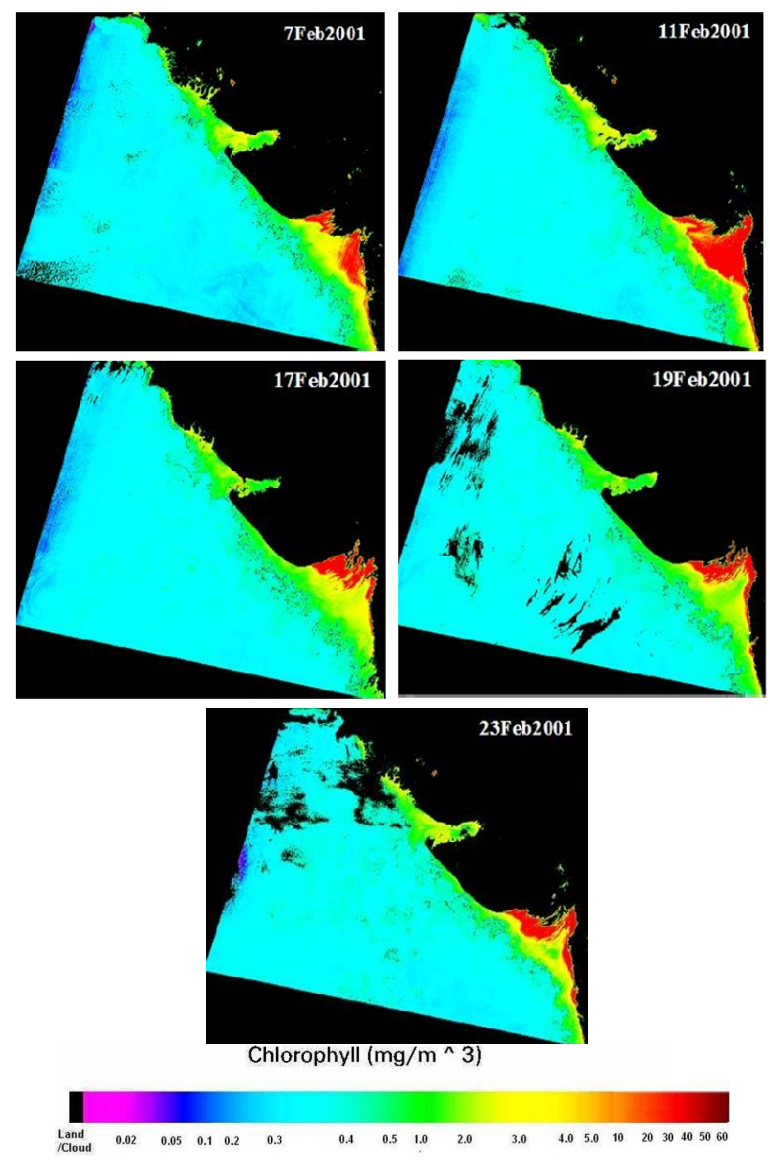

Fig. (3). Spatial distribution of OCM Chlorophyll-a concentration along the west coast of India during 2001.

is a result of positive wind stress curl (i.e., cyclonic vorticity in the wind) and vice versa.

During February 2000 \& 2001, the Ekman Pumping velocities are weak throughout the region and were predominantly north/north-easterly indicating the prevailing winter monsoon conditions. North of $20^{\circ} \mathrm{N}$ region has very low SST $\left(24^{0} \mathrm{C}\right)$ values, the corresponding chlorophyll-a concentration was high $\left(>8 \mathrm{mg} / \mathrm{m}^{3}\right)$ in this region. However, south of $20^{\circ} \mathrm{N}$, conditions are warmer. Satellite observations also showed high chlorophyll concentrations during 1978 79 and $1979-1980$. High concentration of pigments have been observed from IRS-P4 OCM satellite derived chlorophyll images for northern Arabian Sea water around $20^{\circ} \mathrm{N}$ latitude and $65^{\circ} \mathrm{E}$ longitude [14]. This portraits the previous evidence of high chlorophyll-a concentration in the late winter season in the northern part of the Arabian Sea water.

\section{CONCLUSIONS}

Spatial variability of upwelling-related processes along the west coast of India have been described using fine resolution QuickSCAT, Chlorophyll-a and SST. The comparison shows that the chlorophyll-a concentration was high during 2001 to that of 2000, with a $1^{\circ} \mathrm{C}$ difference in SST, but the winds were feeble in 2001. This shows that 

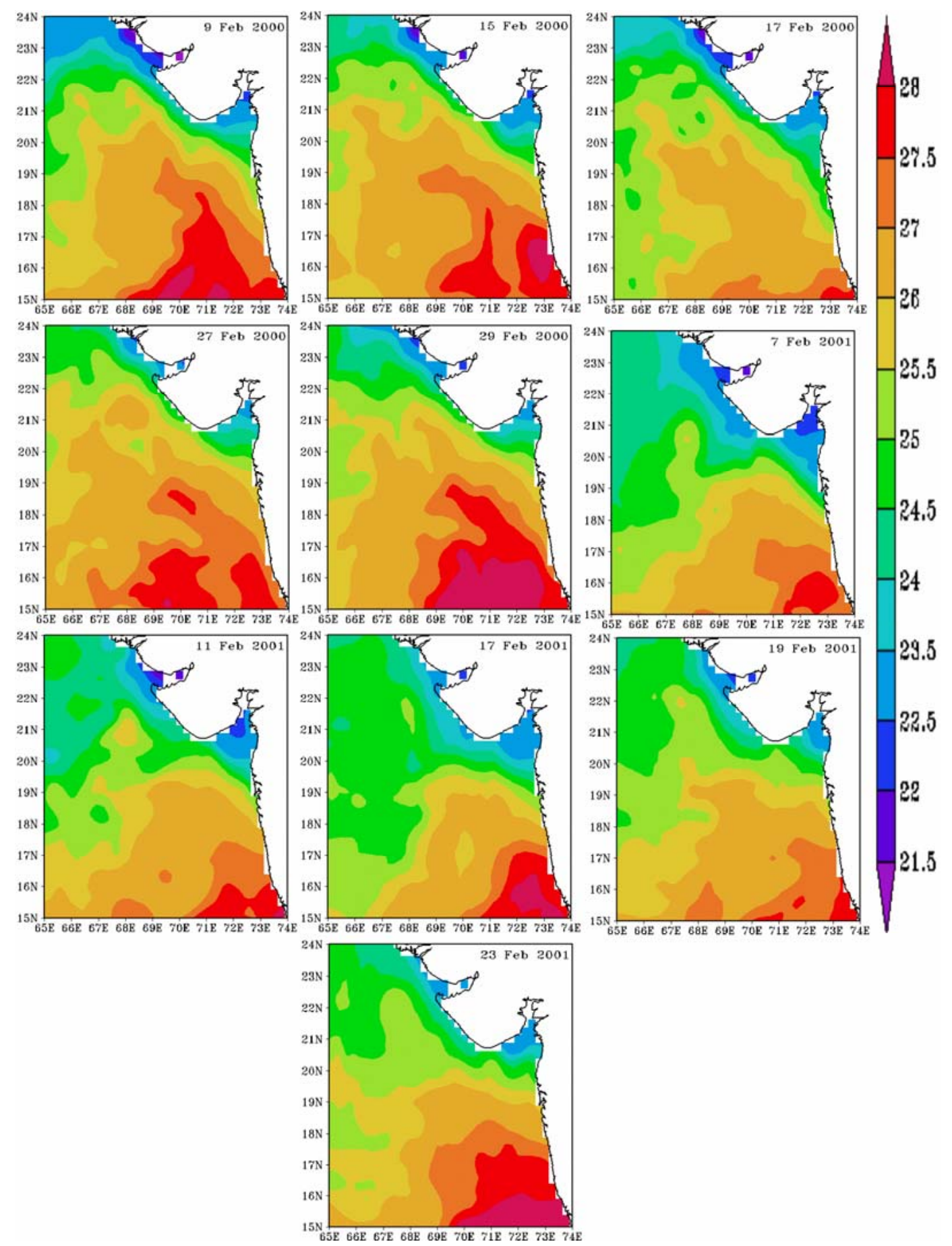

Fig. (4). Spatial distribution of sea surface temperature along the west coast of India.

more cooling took place during late winter period of 2001, than in 2000. The spatial and temporal coverage of coastal upwelling along the west coast of India was still not studied to the maximum extent. The key atmospheric parameter driving the upwelling is wind, so the spatial resolution of the wind field plays a significant role in Ekman Pumping calculations. Ekman pumping is an important mechanism in transporting nutrients to the upper layers. But the amount of nutrient upwelled into the euphotic zone would be controlled by the relative strength of wind-driven mixing (entrainment) and Ekman Pumping. I assume that vertical mixing in the WCI, increased by atmospheric processes such as lowering of SST or wind effects other than evaporation, will enhance nutrient supply to the mixed layer and thus primary production growth rates and concentrations. In view of the importance of coastal upwelling in relation to the air-sea interaction process, in depth study and more insitu observations are required to know the winter cooling phenomena over the northern Arabian Sea. 

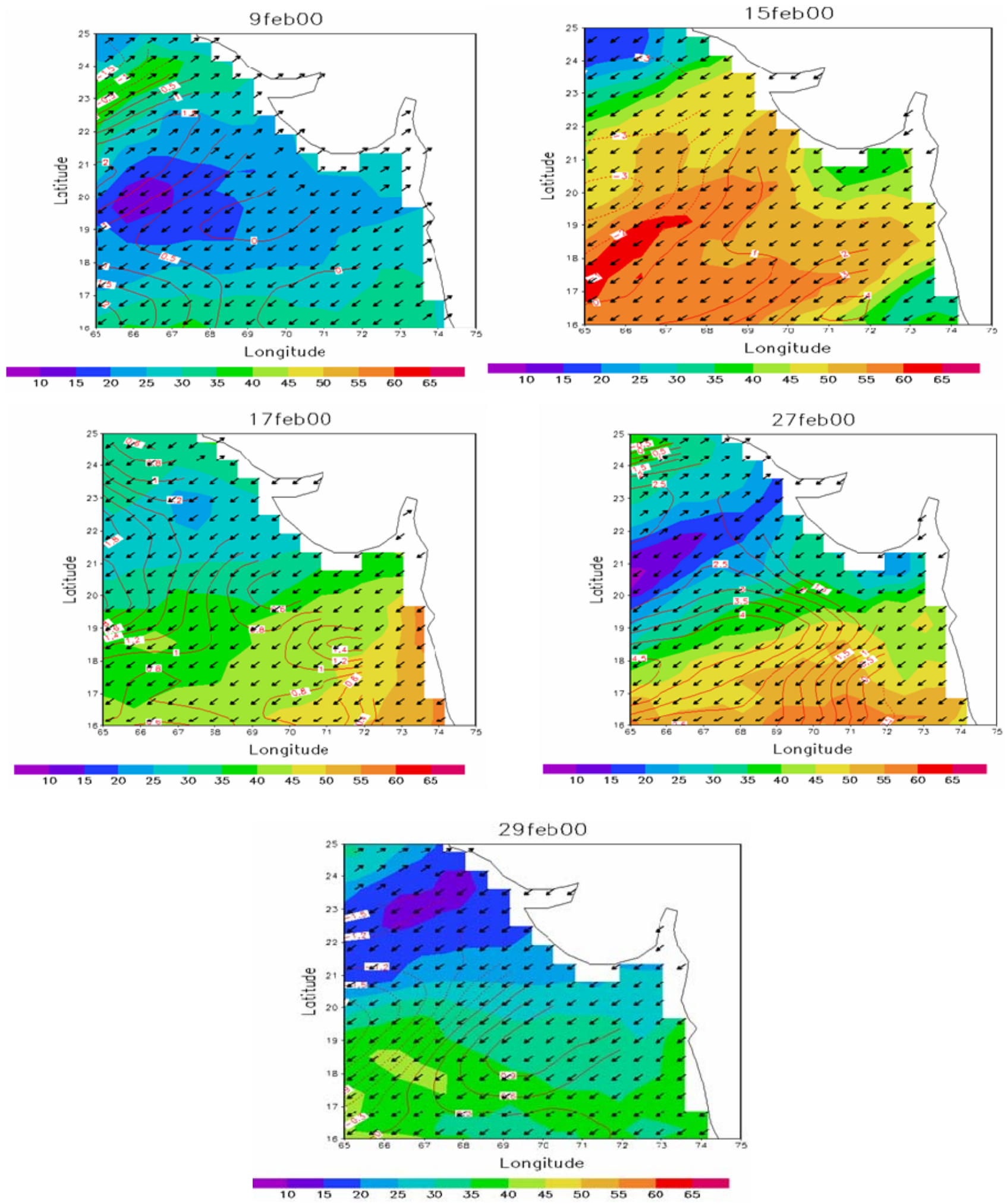

Fig. (5). Spatial distribution of Ekman depth (colour contours), Ekman Pumping ( $\times 10^{-6}$, line contours) and wind stress (vectors) along the west coast of India during 2000.

\section{ACKNOWLEDGEMENTS}

The present research work is supported through funding received from the Department of Science and Technology, Govt. of India under the Fast Track Young Scientist Project (SR/FTP/ES-09/2008) which is gratefully acknowledged. I am grateful to ISRO and The Director, INCOIS, Hyderabad for providing satellite data through their web site. I also thank to Jet Propulsion Laboratory team for providing QuickSCAT and sea surface temperature data. 

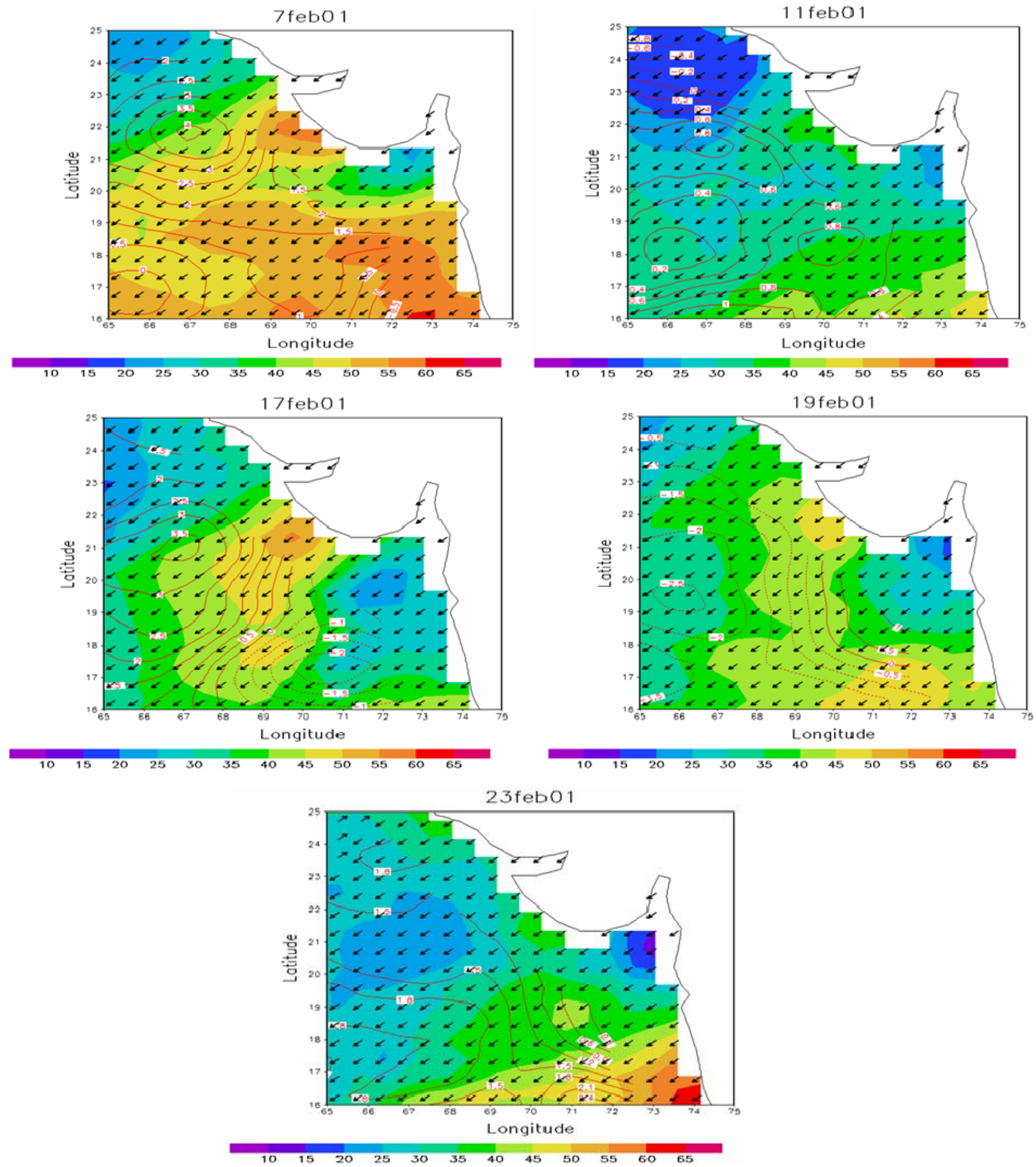

Fig. (6). Spatial distribution of Ekman depth (colour contours), Ekman Pumping (x10 ${ }^{-6}$, line contours) and wind stress (vectors) along the west coast of India during 2001.

\section{REFERENCES}

[1]

[2]
IOCCG. Remote sensing of ocean colour in coastal and other optically complex waters. IOCCG Report Number 3: 2000, p. 143. Lauritsen L, Nelsen GJ, Parte FW. NOAA Tech Memo. NESS, 1979; 107: 73.
Halpern D, Freilich MH, Weller RA. Arabian Sea surface winds and ocean transports determined from ERS -1 scatterometer. J Geophys Res 1998; 103: 7799-805.

Brown OB, Evans RH, Brown JW, Gordon HR, Smith RC, Baker KS. Phytoplankton blooming of the US east coast: A satellite discretion. Science 1985; 229: 163-7.

Kumar PS, Prasad TG. Winter cooling in the Arabian Sea. Curr Sci 1996; 71: 834-41. 
[6] Madhupratap M, Prasanna Kumar S, et al. Mechanism of the biological response to the winter cooling in the northeastern Arabian Sea. Nature 1996; 384: 549-52.

[7] Krishna MK, Rao RS. Seasonal and interannual variability of sea surface chlorophyll a concentration in the Arabian Sea. J Appl Remote Sensing 2008; 2: 1-12.

[8] Hastenrath S, Lamb PJ. Climatic atlas of the Indian Ocean, Part I: Surface climate and atmospheric circulation. University of Wisconsin Press: Madison 1979; WI 19.

[9] Banse K, Mcclain CR. Winter blooms of phytoplankton as observed by the Coastal Zone Colour Scanner. Mar Ecol Progr Ser 1986; 34: 201-11.

[10] Tang DL, Kawamura H. Long-term time series satellite ocean colour products on the Asian waters. Proceedings of the $11^{\text {th }}$
PAMS/JECSS workshop, Seoul, South Korea: Hanrimwon Publishing (CD-ROM: O112-P03), 2001: pp. 49-52.

[11] Yoder JA. An overview of temporal and spatial patterns in satellitederived chlorophyll imagery and their relation to ocean processes. In: Satellite Oceanography and society, Halpern D. (Ed.), Elsevier Science BV: The Netherlands 2000; pp. 225-238,.

[12] Kundu SN, Sahoo AK, Mohapatra S, Singh RP. Change analysis using IRS-P4 OCM data after the Orissa super cyclone. Int J Remote Sensing 2001; 22: 1383-9.

[13] Pond S, Pickard GL. Introductory Dynamical Oceanography, 2nd ed Pergamon: New York 1983; p. 379.

[14] Chauhan P, Nagur CRC, Mohan M, Nayak SR, Navalgund RR. Surface chlorophyll-a distribution in Arabian Sea and Bay of Bengal using IRS-P4 Ocean Colour Monitor (OCM) satellite data. Curr Sci 2001; 80: 40-1.

(c) K. Muni Krishna; Licensee Bentham Open.

This is an open access article licensed under the terms of the Creative Commons Attribution Non-Commercial License (http://creativecommons.org/licenses/by-nc/3.0/) which permits unrestricted, non-commercial use, distribution and reproduction in any medium, provided the work is properly cited. 